2. Yang CJ, Chan DY, Shah SA, Yerokun BA, Wang XF, D'Amico TA, et al. Long-term survival after surgery compared with concurrent chemoradiation for node-negative small cell lung cancer. Ann Surg. 2018;268:1105-12.
3. Raman V, Jawitz OK, Yang CFJ, Voigt SL, D'Amico TA, Harpole DH, et al. The effect of extent of resection on outcomes in patients with limited stage small cell lung cancer. J Thorac Cardiovasc Surg. 2021;161:1483-92.e5.
See Article page 1484 .

\section{Commentary: How much is enough? The extent of resection in small cell lung cancer}

\author{
James J. Choi, MD, MPH, and James Huang, MD
}

Small cell lung cancer (SCLC) is generally seen as a nonsurgical disease, and the mainstay of treatment for limited-stage disease is definitive concurrent chemoradiation. ${ }^{1,2}$ However, there exists a subgroup of patients with limited-stage disease for whom surgery may be an option. The National Comprehensive Cancer Network guidelines suggest that patients with T1-2N0 stage I disease can be considered for lobectomy and mediastinal lymph node dissection, followed by adjuvant chemotherapy in all patients, with mediastinal radiotherapy for those with nodepositive disease. $^{3}$

Raman and colleagues ${ }^{4}$ performed a retrospective analysis of the National Cancer Database (NCDB), investigating survival outcomes on the basis of extent of surgical resection in patients with SCLC. They found poorer survival among patients who underwent wedge resection, compared with lobectomy, and that survival was similar between lobectomy and segmentectomy. Along with a study by Liu and colleagues, ${ }^{5}$ this is one of the first studies to provide more granularity with regard to different sublobar resections for SCLC. Although the sample size was small, with only $5 \%$ of patients undergoing segmentectomy, a propensity score-matched analysis suggested similar survival to lobectomy. In addition, the authors demonstrated that survival with wedge resection alone was no better than

From Thoracic Service, Department of Surgery, Memorial Sloan Kettering Cancer Center, New York, NY.

Disclosures: Authors have nothing to disclose with regard to commercial support.

Received for publication March 4, 2020; accepted for publication March 4, 2020; available ahead of print March 19, 2020.

Address for reprints: James Huang, MD, Thoracic Service, Department of Surgery, Memorial Sloan Kettering Cancer Center, 1275 York Ave, New York, NY 10065 (E-mail: huangj@mskcc.org).

J Thorac Cardiovasc Surg 2021;161:1494-5 0022-5223/ $\$ 36.00$

Copyright $₫ 2020$ Published by Elsevier Inc. on behalf of The American Association for Thoracic Surgery

https://doi.org/10.1016/j.jtcvs.2020.03.010

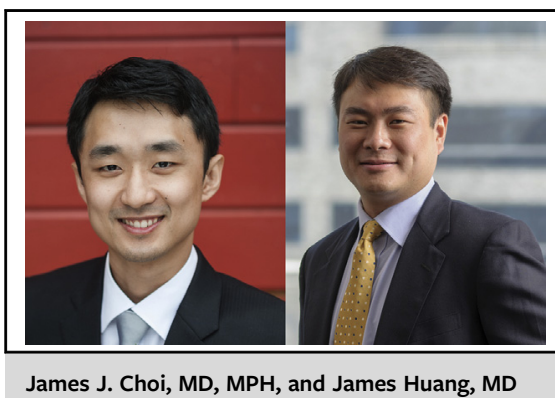

CENTRAL MESSAGE

Segmental and lobar resection

are associated with similar sur-

vival in patients with resectable

CT1-2No stage I SCLC.

when concurrent chemoradiation was given, and they suggest that wedge resection alone is not an acceptable treatment strategy. Interestingly, adjuvant therapy was underused in the wedge resection group, with only $35 \%$ of patients receiving adjuvant chemotherapy and $29 \%$ of patients receiving thoracic radiation. Adjuvant therapy use was surprisingly no better in the segmentectomy and lobectomy groups.

Despite these important findings, the elephant in the room remains selection bias. The authors do acknowledge this directly, but the information necessary for the surgeon to decide on extent of resection is simply not available through the NCDB. Data on tumor factors, such as tissue diagnosis, location in the lobe, and clinical staging, were unavailable. Patient factors were also missing, including pulmonary function and measures of frailty. It seems unlikely that all patients who underwent wedge resection could have also undergone lobectomy, and vice versa.

The authors attempted to account for node status by performing a subgroup analysis including patients with only pathologic node-negative disease, with no significant changes in the conclusion regarding survival outcomes. In addition, the authors performed a subgroup analysis that 
looked at the potential influence of tumor size on the type of resection (segmentectomy vs lobectomy) and found no significant differences. As always with retrospective studies, it is important not to over-read the lack of difference as equivalence, when it may simply reflect a lack of power.

Ultimately, the authors portray a contemporary update on the utility of surgery for the treatment of SCLC, and we congratulate them on their work. Among patients with SCLC in the NCDB, those who were treated surgically and received lobectomy did not appear to do better than those who received segmentectomy, but this conclusion must be tempered within the limitations of small sample size in the segmentectomy group and the dangers of type II error.

\section{References}

1. Fox W, Scadding J. Medical research council comparative trial of surgery and radiotherapy for primary treatment of small-celled or oat-celled carcinoma of bronchus: ten-year follow-up. Lancet. 1973;302:63-5.

2. Lad T, Piantadosi S, Thomas P, Payne D, Ruckdeschel J, Giaccone G. A prospective randomized trial to determine the benefit of surgical resection of residual disease following response of small cell lung cancer to combination chemotherapy. Chest. 1994;106:320S-3S.

3. National Comprehensive Cancer Network. NCCN Clinical Practice Guidelines in Oncology: Small Cell Lung Cancer. Version 3.2020 - February 5, 2020; . Available at: https://www.nccn.org/professionals/physician_gls/pdf/sclc.pdf. Accessed March 1, 2020.

4. Raman V, Jawitz OK, Yang CFJ, Voigt SL, D'Amico TA, Harpole DH, et al. The effect of extent of resection on outcomes in patients with limited stage small cell lung cancer. J Thorac Cardiovasc Surg. 2021;161:1483-92.e5.

5. Liu Y, Shan L, Shen J, Liu L, Wang J, He J, et al. Choice of surgical procedure - lobectomy, segmentectomy, or wedge resection - for patients with stage T1-2N0M0 small cell lung cancer: a population-based study. Thorac Cancer. 2019;10:593-600.
See Article page 1484.

\section{Commentary: Resection for small cell lung cancer should be offered more often, and preferably anatomical}

Kevin Lim, MRCS (Edin), and Michael K. Y. Hsin, FRCS CTh (Eng)

Raman and colleagues from Duke reported a survival analysis of 1948 patients with cT1-2N0 small cell lung cancer (SCLC) who underwent lung resection from 2004 to 2015 , by interrogating the National Cancer Database. ${ }^{1}$ They compared survival after lobectomy with sublobar resection, which they categorized into segmentectomy and wedge resection (WR).

The key findings are (1) a survival advantage in favor of lobectomy and segmentectomy over WR, and (2) survival is equivalent between patients undergoing lobectomy and

From the Department of Cardiothoracic Surgery, Queen Mary Hospital, Hong Kong SAR, China.

Disclosures: Authors have nothing to disclose with regard to commercial support.

Received for publication March 21, 2020; revisions received March 21, 2020; accepted for publication March 22, 2020; available ahead of print April 6, 2020.

Address for reprints: Michael K. Y. Hsin, FRCS CTh (Eng), Department of Cardiothoracic Surgery, Queen Mary Hospital, Hong Kong SAR, China (E-mail: mkhsin@ hotmail.com).

J Thorac Cardiovasc Surg 2021;161:1495-6

$0022-5223 / \$ 36.00$

Copyright (c) 2020 by The American Association for Thoracic Surgery

https://doi.org/10.1016/j.jtcvs.2020.03.084

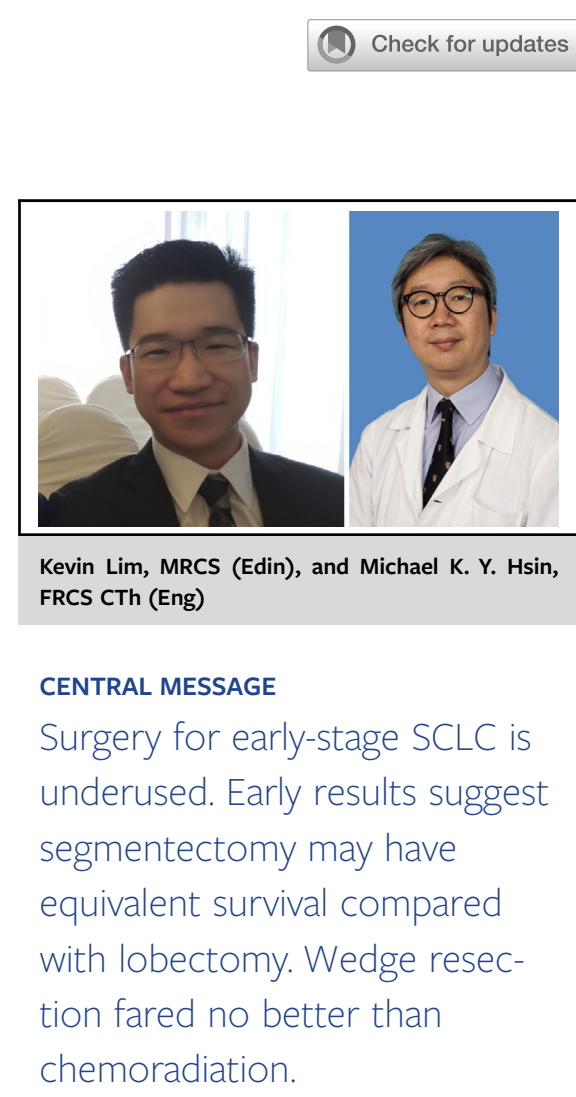

segmentectomy. In a propensity-matched comparison of patients undergoing lobectomy and segmentectomy, survival equivalency held true.

In a subgroup analysis comparing surgery and definitive chemoradiation, survival after lobectomy was superior to chemoradiation, but WR fared no better than 